\title{
An isoleucyl-tRNA synthetase gene from Campylobacter jejuni
}

\author{
Yuwen Hong, Thomas Wong, Billy Bourke and Voon L. Chan
}

Author for correspondence: Voon L. Chan. Tel: +1 416978 6077. Fax: +1 4169784761.

Department of

Microbiology, University of Toronto, Toronto, Ontario, Canada M5S 1 A8

\begin{abstract}
A complete isoleucyl-tRNA synthetase gene (ileS) of Campylobacter jejuni was isolated from a C. jejuni TGH9011 genomic DNA library constructed in pBluescript. The complete coding sequence, flanking regions and transcription start point were determined. The deduced isoleucyl-tRNA synthetase (IleRS) had 917 amino acids with a molecular mass of $105399 \mathrm{Da}$, which was consistent with the observed size of $105 \mathrm{kDa}$ in Escherichia coli maxicells. The ileS gene was mapped onto the physical map of the $C$. jejuni genome. Alignment of the $\boldsymbol{C}$. jejuni lleRS sequence with six other bacterial lleRS sequences and two lower eukaryotic lleRS sequences identified seven conserved motifs, including the two signature sequences, HIGH and KMSKS, of class I aminoacyl-tRNA synthetases.
\end{abstract}

Keywords: isoleucyl-tRNA synthetase (IleRS), alignment of bacterial IleRS, conserved motifs

\section{INTRODUCTION}

The ileS gene encodes isoleucyl-tRNA synthetase (IleRS), an essential enzyme needed for the aminoacylation of isoleucyl tRNA. The 20 aminoacyl-tRNA synthetases (aaRSs) have been divided into two classes based on some conserved amino acid sequences and structural motifs (Webster et al., 1984; Ludmerer \& Schimmel, 1987; Schmidt \& Schimmel, 1993; Eriani et al., 1990; Cusack et al., 1990; Burbaum \& Schimmel, 1991a; Chalker et al., 1994). IleRS is a class I aaRS enzyme that contains some well-conserved domains contributing to the catalytic core of the enzyme (Shiba \& Schimmel, 1992; Burbaum \& Schimmel, 1991b; Rould et al., 1989). A conserved domain, the HIGH tetrapeptide, is located close to the Nterminus. A more conserved domain, KMSKS, is located around 600 amino acids away from the $\mathrm{N}$-terminus (Moras, 1992; Shepard et al., 1992).

ileS genes have been isolated and completely sequenced from Escherichia coli (Webster et al., 1984), Staphylococcus aureus (Chalker et al., 1994; Hodgson et al., 1994), Methanobacterium thermoautotrophicum (Jenal et al., 1991), Saccharomyces cerevisiae (Martindale et al., 1989) and from a protozoan Tetrabymena thermophila (Csank \& Martindale, 1992). Partial sequences of the same gene from Pseudomonas fuorescens (Isaki et al., 1990a) and Enterobacter aerogenes

Abbreviation: aaRSs, aminoacyl-tRNA synthetases.

The GenBank accession number for the nucleotide sequence reported in this paper is U15295.
(Isaki et al., 1990b) have also been published. Campylobacter jejuni is a major causative agent of bacterial diarrhoea in humans. Despite this, molecular biological understanding of $C$. jejuni is in its infancy. To date, only a handful of genes have been isolated, sequenced and characterized (Hani \& Chan, 1994; Louie \& Chan, 1993; Pei \& Blaser, 1993; Labigne et al., 1992; Chan \& Bingham, 1991, 1992; Fisher \& Nachamkin, 1991; Nuijten et al., 1990; Kim \& Chan, 1989).

In this study, we report the isolation, mapping and characterization of the $C$. jejuni ileS gene. The deduced IleRS sequence was compared to IleRS sequences of other organisms with the aim of identifying conserved motifs.

\section{METHODS}

Bacterial strains and other materials. C. jejuni TGH9011 (ATCC 43431, serotype reference strain for O:3) was obtained from J. L. Penner (University of Toronto, Toronto, Ontario, Canada). E. coli DH5 $\alpha$ (this laboratory) and E. coli DR1984 (Sancar et al., 1979) were grown routinely in LB broth; LB and M9 minimal agar medium were supplemented with nutrients and/or antibiotics as required; when appropriate, ampicillin was added to a final concentration of $50 \mu \mathrm{g} \mathrm{ml}^{-1}$. All restriction endonucleases and other enzymes were purchased from either Pharmacia or Boehringer Mannheim. $\left[\alpha^{32} \mathrm{P}\right]$ ATP, $\left[\gamma-{ }^{32} \mathrm{P}\right]$ A TP and $\left[{ }^{35} \mathrm{~S}\right]$ methionine were from ICN Biomedicals. The sequencing kit was purchased from United States Biochemical.

iles gene isolation. The $C$. jejuni chromosomal DNA library used was constructed previously in pBluescript $(\mathrm{H}$. L. Bingham $\&$ V. L. Chan, unpublished data). One particular C. jejuni DNA 
clone containing a complete ileS gene, designated as E8-1 $(8.85 \mathrm{~kb})$, was isolated as a false positive clone in screening with a ${ }^{32}$ P-labelled PCR fragment that was obtained from two degenerate primers designed for the isolation of the $d n a A$ gene.

Restriction mapping and subcloning. The HindIII and EcoRV sites in the $C$. jejuni genomic DNA insert in E8-1 were mapped by the partial digestion method (Smith \& Birnstiel, 1976). Three HindIII fragments $(2 \mathrm{~kb}, 0.3 \mathrm{~kb}$ and $1 \mathrm{~kb})$ at the $3^{\prime}$ end of the E8-1 insert and two EcoRV fragments were subcloned individually into pUC19 and propagated in E. coli DH5 .

Construction of deletion derivatives. A unidirectional DNA deletion with the Erase-a-Base system was accomplished essentially as described by Henikoff (1984). The above $2 \mathrm{~kb}$ and $1 \mathrm{~kb}$ HindIII subclones were digested with $K p n \mathrm{I}$ and SalI to generate a $3^{\prime}$ and a $5^{\prime}$ overhang, respectively. Approximately $2 \mu \mathrm{g}$ of the linearized DNA was then digested with exonuclease III and $\mathrm{S} 1$ nuclease, ligated with $\mathrm{T}_{4}$ DNA ligase and then transformed into $E$. coli $\mathrm{DH} 5 \alpha$ cells to generate the nested deletion clones.

DNA sequencing analysis. Both strands of the ileS gene were sequenced using the dideoxy chain-termination method of Sanger et al. (1977) and the Sequenase Version 2.0 from United States Biochemical.

Primer extension analysis. A primer extension analysis was performed to locate the transcription start site. RNA was extracted from $C$. jejuni by the hot phenol method (Aiba $e t$ al., 1981). Oligonucleotide 5' TCAAGTTCCGCTAAATTCGCCCGC $3^{\prime}$ is complementary to the coding strand of ileS and is located at nucleotides 48-71 downstream from ATG, the initiation Met codon of the ileS gene. This oligonucleotide was end-labelled with $\left[\gamma_{-}{ }^{32} \mathrm{P}\right] \mathrm{ATP}$ and polynucleotide kinase. Labelled oligonucleotide (30 ng) (approximately $1 \times 10^{7}$ c.p.m.) was mixed with $25 \mu \mathrm{g}$ total RNA of $C$. jejuni. The mixture was hybridized and extended as described previously by Chan \& Bingham (1992). For analysis, $4 \mu$ of the newly synthesized DNA (previously suspended in $8 \mu$ l formamide loading buffer) was loaded onto a $6 \%(\mathrm{w} / \mathrm{v})$ polyacrylamide sequencing gel alongside dideoxy sequencing ladders of the upstream flanking region of the iles gene.

Analysis of plasmid-encoded protein. The ileS gene from $C$. jejuni was expressed in E. coli DR1984 by the maxicell protocol described by Sancar et al. (1979). E8-1-bearing DR1984 cells were grown in M9 medium plus $1 \%(\mathrm{w} / \mathrm{v}$ ) Casamino acids and were UV-irradiated at a cell concentration of $2 \times 10^{8} \mathrm{ml}^{-1}$ for 30 or $40 \mathrm{~s}$ with a $15 \mathrm{~W}$ germicidal lamp set at a height of $50 \mathrm{~cm}$. The survival was between $10^{-5}$ to $10^{-6}$ following a $15 \mathrm{~h}$ incubation in M9 medium containing $200 \mu \mathrm{g} \mathrm{D}$-cycloserine $\mathrm{ml}^{-1}$. Proteins encoded by the plasmid DNA were labelled with $\left.{ }^{35} \mathrm{~S}\right]$ methionine and resolved by SDS-PAGE $(1 \%, \mathrm{w} / \mathrm{v}$, SDS; $6 \%, \mathrm{w} / \mathrm{v}$, polyacrylamide) (Laemmli, 1970) and visualized by autoradiography.

IleRS assay. In order to test the function of the IleRS expressed by the ileS gene, recombinant clone E8-1 was transformed into E. coli 331 $\mathrm{c}^{-}$(Isaksson et al., 1977), which is a temperaturesensitive strain due to a mutation of the chromosomal ileS gene (kindly provided by Dr H. C. Wu, Uniformed Service University of the Health Sciences, Bethesda, MD, USA). Both recipient $E$. coli $331 \mathrm{c}^{-}$and $E 8-1$-bearing $331 \mathrm{c}^{-}$cells were grown in $\mathrm{LB}$ medium at $32{ }^{\circ} \mathrm{C}, 37^{\circ} \mathrm{C}, 40^{\circ} \mathrm{C}$ and $42^{\circ} \mathrm{C}$. The activity of IleRS was measured by its ability to charge tRNA with $\mathrm{L}^{-}$ $\left[{ }^{3} \mathrm{H}\right]$ isoleucine, as described by Chan \& Bingham (1992) with minor modification. In a $100 \mu \mathrm{l}$ reaction volume, $0.64 \mu \mathrm{M}$ ATP, $40 \mu \mathrm{M}$ Tris $/ \mathrm{HCl}(\mathrm{pH} 8.6), 4 \mu \mathrm{M}$ magnesium acetate, $0.000044 \mu \mathrm{M} \mathrm{L}-\left[4,5{ }^{3} \mathrm{H}\right]$ isoleucine and $80 \mu \mathrm{g} E$. coli $\mathrm{tRNA}$ were used. Crude cell extract $(10 \mu \mathrm{g})$ from $331 \mathrm{c}^{-}$or E8-1-bearing $E$. coli $331 \mathrm{c}^{-}$was added and incubated at $25^{\circ} \mathrm{C}$ for $15 \mathrm{~min}$. The reactions were terminated by adding $20 \mu \mathrm{l} 5 \%(\mathrm{v} / \mathrm{v})$ trichloroacetic acid $/ 0.05 \%$ Casamino acids and the complete reaction mixtures were spotted onto $2.4 \mathrm{~cm} 3 \mathrm{MM}$ Whatman disks. The disks were washed three times with $10 \mathrm{ml}$ ice-cold $5 \%$ trichloroacetic acid $/ 0.05 \%$ Casamino acids, twice with $10 \mathrm{ml} 95 \%(\mathrm{v} / \mathrm{v})$ ethanol, dried and counted in a liquid scintillation system.

Mapping of the ileS gene in the $\boldsymbol{C}$. jejuni genome. The ileS gene was mapped by Southern hybridization using a ${ }^{32} \mathrm{p}$ labelled $2 \mathrm{~kb}$ HindIII fragment of E8-1 as the probe. The $C$. jejuni genome was digested with $S m a \mathrm{I}, S a l l$ and $S a c \mathrm{II}$ and fragments were resolved by PFGE as described by Kim et al. (1992).

\section{RESULTS}

\section{Cloning of the iles gene}

Two 17-mer degenerate primers (GAG/AGAG/ ATTATTACAC/TAC and GTG/ATGATCT/ACG/ TNCCNCC) synthesized on the basis of two conserved motifs of the DnaA protein of eubacteria amplified a $600 \mathrm{bp}$ fragment which was used to screen the pBluescript genomic library of $C$. jejuni. Clone E8-1 was one of the hybridizing clones and has an insert of about $6 \mathrm{~kb}$. The HindIII and EcoRV sites in the E8-1 insert were mapped. Southern hybridization using the PCR-amplified fragment as a probe localized the hybridizing region to the $3^{\prime}$ terminal HindIII fragment of the insert. This region was sequenced and shown to have high homology to the Cterminal IleRS sequence of various organisms as determined in a database search using the Blast program (Altschul et al., 1990). The complete IleRS coding sequence was shown to be localized to three adjacent HindIII fragments $(2 \mathrm{~kb}, 0.3 \mathrm{~kb}$ and $1 \mathrm{~kb})$.

\section{Nucleotide sequence of the ileS gene}

The complete IleRS-coding sequence was determined to show a 2751 nucleotide ORF which encodes a 917 amino acid protein with a predicted molecular mass of $105399 \mathrm{Da}$. The $\mathrm{N}$-terminal sequence of the $C$. jejuni IleRS and its 5'-flanking region are shown in Fig. 1, where the proposed start codon is indicated. Eleven nucleotides

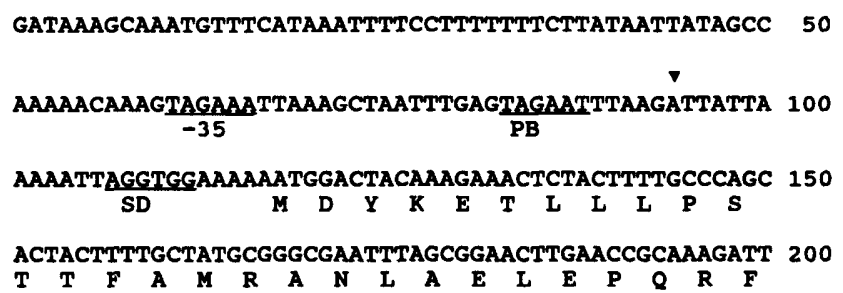

Fig. 1. The $\mathrm{N}$-terminus of the $\mathrm{C}$. jejuni lleRS coding sequence and its flanking region. The transcription start site, residue $A$ (located at nucleotide 94), is marked by an inverted solid triangle. The potential Shine-Dalgarno sequence (SD), Pribnow box (PB) and -35 consensus regions are indicated by solid underlining. 


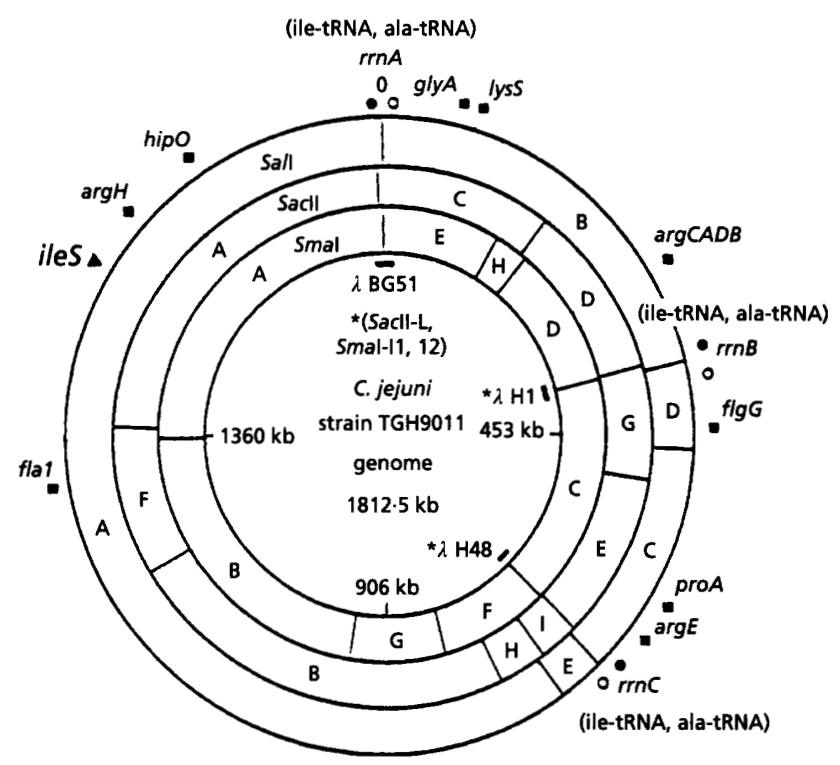

Fig. 2. Physical map of $C$. jejuni TGH9011 (Kim et al., 1993). The location of the ileS gene was identified by hybridization of the 2 kb Hindlll fragments of E8-1 to Sall A, Sacll A and Smal A bands of $C$. jejuni DNA resolved in agarose using PFGE.

upstream from the start codon, a sequence, AGGTGG, matches five of the six nucleotides of the Shine-Dalgarno sequence.

The $5^{\prime}$ end of the ileS mRNA was located by primer extension at nucleotide 94 , residue $A$ in the sequence (see Fig. 1). Eleven nucleotides upstream of the transcription start point is a sequence, TAGAAT, which matches five of the six nucleotides of the Pribnow box and 33 nucleotides upstream is a sequence, TAGAAA, which matches four of the six nucleotides of the consensus -35 sequences.

\section{Maxicell analysis}

Proteins encoded by the $8.8 \mathrm{~kb}$ E8-1 clone were determined using the maxicell system. pBluescript DNA encoded $31 \mathrm{kDa}$ and $28 \mathrm{kDa}$ proteins representing precursor and mature $\beta$-lactamase, respectively. An extra polypeptide of $105 \mathrm{kDa}$ was encoded by the E8-1 clone which likely represents the IleRS protein as it conforms to the size predicted from the gene sequence.

\section{Temperature complementation test and enzyme assay}

Plasmid E8-1 containing the complete ileS gene was unable to restore growth of E. coli $331 \mathrm{c}^{-}$at $42{ }^{\circ} \mathrm{C}$. However, the enzyme assay revealed an approximately threefold increase in IleRS activity after $E$. coli $331 \mathrm{c}^{-}$was transformed with E8-1. The IleRS activities in extracts of E8-1 transformed and nontransformed E. coli $331 c^{-}$cells were completely inactivated after $5 \mathrm{~min}$ incubation at $50{ }^{\circ} \mathrm{C}$ (data not shown), suggesting thermal sensitivity of the $C$. jejuni TGH9011 IleRS proteins. IleRS thermal sensitivity may have contributed to the failure of complementation of the $E$. coli temperature sensitive mutant.

\section{Mapping of the ileS gene in C. jejuni genomic DNA}

The genomic size of $C$. jejuni TGH9011 is approximately $1812 \mathrm{~kb}$ (Kim et al., 1993). The mapping of the ileS gene in the $C$. jejuni genome showed that the ileS gene probe hybridized to the PFGE $S m a \mathrm{I} A, S a l$ A and SacII A fragments. Thus, the ileS gene is located in the $1360-1812 \mathrm{~kb}$ region of the genomic map of $C$. jejuni TGH9011 (Fig. 2).

\section{Comparison of the ileS gene from different organisms}

The amino acid sequence encoded by the $C$. jejuni ileS gene showed a high level of homology to the ileS gene product of E. coli (Webster et al., 1984; Yu et al., 1984), Staph. aureus (Chalker et al., 1994; Hodgson et al., 1994), $M$. thermoautotrophicum Marburg (Jenal et al., 1991), Sac. cerevisiae (Martindale et al., 1989) and T. thermophila (Csank \& Martindale, 1992) as shown in Fig. 3.

Two signature sequences, HIGH and KMSKS, of class I aaRS can be seen in Fig. 3 at amino acids 66-69 and 610-614 in IleRS. Five other conserved motifs can also be observed at amino acids 95-104, 235-242, 319-333, 465-477 and 569-578 in IleRS.

\section{DISCUSSION}

A C. jejuni pBluescript recombinant clone, E8-1, was shown to contain the ileS gene. This gene is $2751 \mathrm{bp}$ in size and the sequence predicts an IleRS protein of 917 amino acids with a molecular mass of $105399 \mathrm{Da}$. Maxicell analysis provided support for a molecular mass of $105 \mathrm{kDa}$. The size of the $C$. jejuni IleRS enzyme is similar to that of the other bacteria. For instance, the IleRS enzymes of E. coli $\mathrm{K} 12$ and Staph. aureus are 939 amino acids (Webster $e$ t al., 1984) and 918 amino acids (Chalker et al., 1994), respectively. On the other hand, the IleRS protein of $M$. thermoautotrophicum (1045 amino acids) and a number of eukaryotic IleRS proteins including Sac. cerevisiae (1072 amino acids) (Martindale et al., 1989) and T. thermophila (1081 amino acids) (Csank \& Martindale, 1992) are somewhat longer.

Despite differences in the size of IleRS enzymes among different species, their sequences show a high degree of homology (Fig. 3). Multiple alignment analysis of all the IleRS sequences reported so far (Webster et al., 1984; Chalker et al., 1994; Hodgson et al., 1994; Jenal et al., 1991; Martindale et al., 1989; Csank \& Martindale, 1992; Isaki et al., 1990b; gene accession number S40549 in GenBank) identified seven conserved motifs. Two domains among the motifs, the 'HIGH' in motif $\mathrm{I}$ and 'KMSKS' of motif VII, are conserved in almost all class I aaRSs. Among the four residues HIGH in motif I, only the first histidine and the third glycine were almost invariant and were involved in ATP binding (Moras, 1992). Our alignment analysis proved that the $\mathrm{H}$ and $G$ 
Cj
100

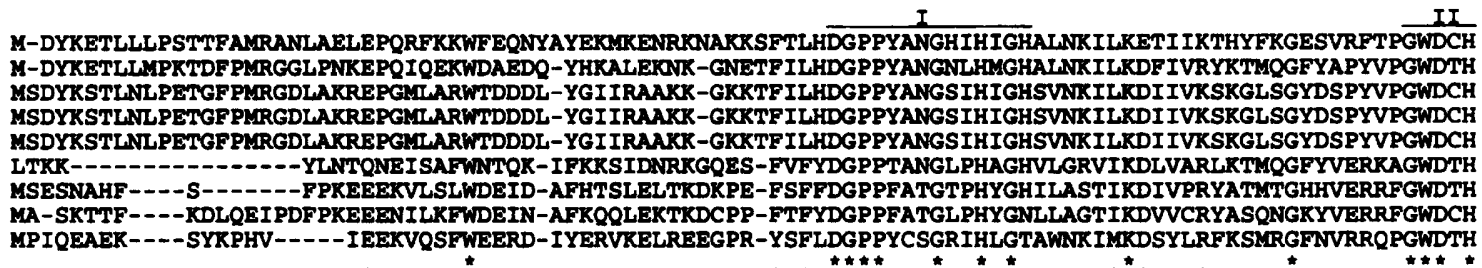

GLPIEQQVEVKLGEKKK------SLSKKEIREFCRQHASEFVDIQREEFKNLGI IADWDKPYLTMKF-EFEAAIYRTLCEIAKKGLLCERSKPVFWSWAAR GLPIEQALTKK-GVDRK-----KYSTAEFREKCKEFALEQIELQKKDFRRLGVRGDFNDPYITLK-PEYEAAQIRIFGEMUDKGLIYKGKKPVYWSPSSE GLPIELKVEQEYGKPGE-----KFTAAEFRARCREYAATQVDGQRKDFIRLGVLGDWSHPYLTYDFKT-EANI IRALGKI I GNGHLHKGAKPVHWCVDCR GLPIELKVEQEYGKPGE-----KFTAAEFRAKCREYAATQVDGQRKDF IRLGVLGDWSHPYLTYLDFKT-EANI IRALGKI IGNGHLHKGAKPVHWCVDCR GLPIELKVEQEYGKPGE-----KFTAAEFRARCREYAATQVDGQRKDF IRLGVLGDWSHPYLTMGLQNWTANI IRALGKI IGNGHLHKGAKPVHWCVDCR GLPVELEVEKKX I GIKGKODIE-KYGI ENF INECKKSVFNYEKEWRDF SKDLGYWVDMDSPYITLE-NNYIESVWNILSTFHKKGLLYKGHKVTPYCTHDO GVPIEHI IDKKLGITGKDDVF-KYGLENYNNECRSIVMTYASDWRKTI GRLGRWIDFDNDYKTWYY-PSFMESTWWAFKOLHEKGQVYRGFKVMPYSTGLT GLPVEYEIDKRLGITNRQEVL-KWGVDKYNAECRSIVMRYAQEWRS IVNRFGRWVDPDNDYKTLD-LKFMESWWWVFKQMFDKGLVYRGCKVMPYSNGCA GLPIEHKVEGILGVRSKDIEDKIGIEEFVRKCREFAMIENKAVMTSQFQRLGVWMDWDDPYVTFD-PAYMESCWWTLKRAHEKDLLLRDLRVITWCPRCE

SALAEAEVEYQDKEDYSIFVAFD-LDVKACK-KLGVSKASA----VIWTTTPWTLVANQAIALNPNENYV-----ITKEGLIFASALLKSMVEK---GLT SSLAEAEIEYHDKRSASI YVAFNVKDDKGV-.---.---VDADAKF I IWTTTPWTI PSNVA ITVHPELKYGQ- - YNVNGEEKY I IAEALSDAVAEALDWDKA SALAEAEVEYYDKTSPSIDVAFQAVDQDALKAKFAVSNVNG ISLVIWTTTPWTLPANRAISIAPDFDYALV --QIDGQAVILAKDLVESVMQRIG--VT SALAEAEVEYYDKTSPSIDVAFOAVDQDALKARFAVSNVNGPISLVIWTT-RRGLCLPTAOSLIHQIS-THRWWQIDGQAVILAKDLVESVMQRIG--VT SALAKRKISITTKLLRPSTLLSRAVDQDALRAKFAVSNVNGPISLVIWTTT PWTLPANRAISIA PDFDYALV--QIDGQAVILAKDLVESVMQRIG--VT TALSSHEVA---------QGYKNVKDL SAVVKFQLTN-SKDTYFL SWTTTPWTLPANVALAINKDLNYSKI--RVENEYYILATDLINSIIT - - ---E TPLSNFEAQ--.---- QNYKDVNDPAVTIGFNVIG-QEKTQLVAWTTT PWTLPSNLSLCVNADFEYVKI YDETRDRYF ILLESLIKTLYKKRK--NE TVLSNFETQ-------QNYKEVDDPSLFIAFKTAE-DPKTKFIAWTTTPWTLPSNLALVINKDFDYVKVLDAKTQEKYILAECRL PEL YKKDK--DG TALALAEID------YHEKEDPSIYVKFPVSG-D--TYILVWTTTPWILPANKAVAVHPDFDYAHT--RLDGETYIMAEALVEKVL-----GE $\bullet$

IV

SGEIOKELNAKEFEKLEAINPL-----NGRKSVI IMGEHVLMDGGSGLVHTAPGHGEDDYYACLKYGI---- EVLMPVDDSGCYDETLRAKRILPSH SIKLEREYTGKELEYVVAOHPF-_-_--LDRESLVINGDHVTTDAGTGCVHTAPGHGEDDYIVGOKYEL-DYTILGTVKGADVELLRFTHPF------MGFDVPAILGDHVTLDAGTGAVHTAPGHGPDDYVIGQKYGL---- ETANPVGPDGTY--- - ----LPGT DYTILGTVKGADVELLRFTHPF--- ---MGFDVPAILGDHVTLDAGTGAVHTAPGHGPDDYVIGQKYGL-----ETANPVGPDGTY---------LPGT D-SRHGKRCGAGAAA--FTHPF-----MGFDVPAILGDHVTLDAGTGAVHTAPGHGPDDYVIGQKYGL-----ETANPVGPDGTY---------LPGT KYEI IDTF SGSNLINLKYIP--PFESDGLVNAYY - VVDGEFVTNSEGTGIVHIAPAHGEDDYQLVLERDL-----DFLNVITREGVYNDRF-------KYKIVEKIKGSDLVGLKYEPLFPYFAEQFHETAFRVISDDYVTSDSGTGIVINAPAFGEEDNAACLRNGVISEDSVLPNAIDDLGRFTKDV-------FDDDYKVSVANNIIKPDDP-PVPVDENGHFTNVV--.-20EAEI IKTVRGSELEGLTYRHPLDEEVPCHRDMEHRVILGDHVTLTEGTGCVHTAPGHGPEDFEIGKEYGL-----PVFCPVDEAGVFTEDA---------

LLEEF IGLHIFKANEKILELLGEK--LLHSSKFIHSYPFCWRTHKPVIYRATKQWFILWDEPKLQGKTLRECAKEQLLKTTFYPQSGV-KRIGSMVENRP --GQFEGYFYDKANKAVTDLLTEKGALLKLDFITHSYPHDWRTKKPVI FRATPQWFASISK--VRQDILDAI ENTN-----FKVNWGK-TRIYNMVRDRG Y-PTLDGVNVFKANDIVVALLQEKGALLKVEKSQHSYPCCWRHKTPI IFRATPQWFVSIDQKGLRAQSLKEIKGVQ-----WIPDWGQ-ARIESYVANRP Y-PTLDGVNVFKANDIVVALLQERGALLHVEKYQHSYPCCWRHKTPI IFRATPOWFVSUDQKGLRAOSLKEIKGVO-----WI PDWGQ-ARIESWVANRP Y-PTLDGVNVFKANDIVAALLQEKGALLHVEKYQHSYPCCWRHKTPI IFRATPQWFVSMDQRGLRAQSLKEIKGVO----WIPDWGQ-ARIESMVANRP

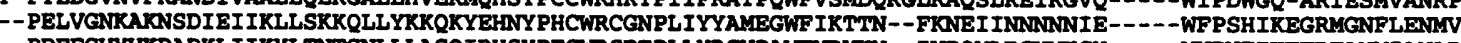
- - PDFEGVYVKDADKL I IKYLTNTGNLLLASQIRHSYPFCWRSDTPLLYRSVPAWFVRVKN--IVPQMIDSVIRSH-_---WVPNTIKEKRFANWIANAR --SDFAGVYI KEADKLIRKNLKERGLLLVDSSFKHNYPFCWRSDTPLIYKAVHCWF IKVTA--LKDDLLANNKRAY-----WVPKFAQEGRFNNWLQNVS --GKYRGLFVKDADSDI IDDLRSKNLLLRAETISHRYGFCWRCKTPI IYLATEQWFLKITE--IKDKGLSELDRVQ----WI PSWAGESRFRNFIENAR V

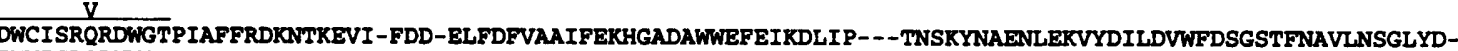
BWVISRQRVWGVPLPVFYAENGEI IM-TK--ETVNHVADLFAEHGSNIWFEREAKDLLPEGETHPGSPNGTFTKETDIMDVWFDSGSSHRGVLETRP-EDWCISRQRTWCVPUSLFVHKDTEELH-PRTLELMEEVAKRVEVDGIQAWWDLDAKEIL-_-_-GDEADQYVKVPDTLDVWFDSGSTHSSVVDVRP-EDWCISRORTWGVPUSLFVHKDTEELH-PRTLELMEEVAKRVEVDGIOAWWDLDAKEIL____._-GDEADOYVKVPDTLDVWFDSGSTHSSVVDVRP-EDWCISRORTWGVPUSLFVHKDTEEIH - PRTLEIMEEVAKRVSVDGIOAWWLDAKEII_- - - -GDSADOYVIVPDTI.DVWFDSGSTHSSVVDVRP-EDWNIGRNRYWGTPLNVWICNDCNHEYAPSSIKDLQNNS INKIDEDIELHRPYVDNITLS-----CPKCNGKUSRVEEVIDVWFDSGSYPFAQHHY-PFDDWNVSRNRYWGTPIPLWVSDDFEEVVCVGSIKELEE--LTGVRNITDLHRDVIDKLTIP----SKQGKGDLKRIEEVFDCWFESGSWPYASQHY - PFEDWCFSRSRFWGNPI IWVSEDFEEVVCIGSVEELKK - -LTGATEITDLHKDF IDHLTIP---- SQKGKGVLRRIDEVFDCWFESGSUPYGQQHY-PFSY DWTISRQRYWG IPI PIWVCEDCDSIHVVGSIGELRELAVEGQLEGDFIHRPHVDRIILE-----CGRCGGRMKRTPDVLDVWIDSGVAGWAALHY-P--R

$$
\mathrm{VI}
$$

559 - VII

546 56 --LS-FPADMYL-EGSDQYRGWFNSSI TTSVATRGVSPYKFLLSHGFVIDGEGKKISKSLGNVIVPDQVVKQRGADIARLWVSSTDYL--ADVRISDE 551 ----FAGHAADUYL-EGSDQHRGWFUSSLMISTAYKGXAPYCQVLTHGFTVDGQGRKISRSIGNTVSPQDVMNLGADILRLWVASTDYT--GQYAVSDE 551 ----FAGHAADWYL-EGSDQHRGWFMSSLYISTAMKGKAPYCOVLTHGFTVDGQGRKUSKSIGNTVSPQDVMNKLGADILRLWVASTDYT--GQYAVSDE 550 ----FAGHAADWYL-EGSDQHRGWFSSLMISTAYKGKAPYRQVLTHGFTVDGQGROUSKSIGNTVSPQDVMNLGADILRLWVASTDYT--GEYAVSDE 529 NQKIFNQHFPADFIAEGVDQTRGWFYSLLVISTILKGKSSYKRALSLGHILDSNGKKASKSKGNVINPTELINKYGADSLRWALISDSAPWNNK-RFSEN 546 NTEKFDERVPANFISEGLDQTRGWFYTLAVLGTHLFGSVPYINVIVSGIVLAADGRKYSKSLKNYPDPSIVLNKYGADALRLYLINSPVLKAESLKFKEE

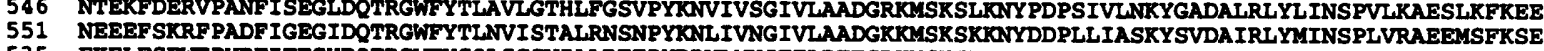

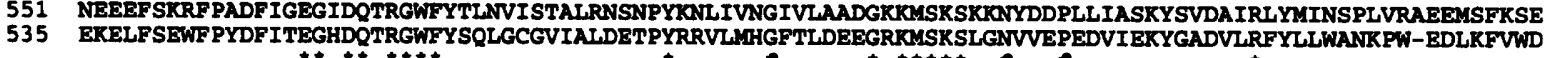

Fig. 3 For legend see facing page.

are completely conserved in all the IleRSs, including in those from Archea and Eukarya species. Moreover, based on the consensus sequence in class I aaRSs, an 11-mer peptide that ends in HIGH is highly conserved and is considered a 'signature sequence' for class I aaRSs (Burbaum \& Schimmel, 1991b). Among the IleRSs, this 
ILKQV-GEQYRKIRNTIRFLLANTW-------DLKD----LEVKEFSFIDKWILSRASKVFKASKEAFFAYEFAKGFSLLLN-FLSADLSGIYLDIS ILKOT-SDVYRK IRNTIRFULGNIN-- - - - --DFNPDTDSIPESEILLEVDRYLINRLREFTASTIMAYENEDYLNIYOEVON-FINVELSNEYLDYG

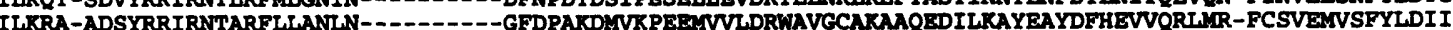

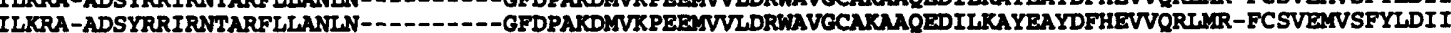

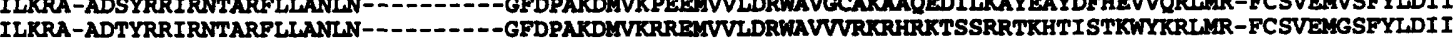

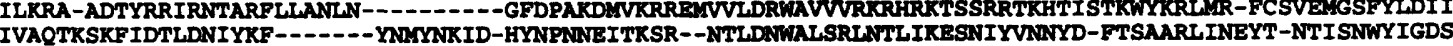

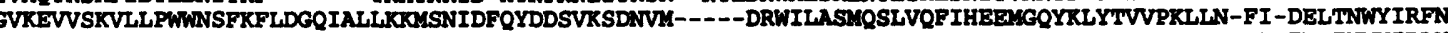
GVFAVKKDIFL PWYNAYKRLIQS ITRWELATGKDYIFNEQLSVDTTKLTNPTDRNIIISCQNLINYVRIEVEKYHLYNVVPRLIH-FL-ENLTNWY IRLN ELKNV-NKOFNILWNVYVFATT-_..--YMSLD-RFQPGDHELEDLHFRDEDRWI ISRVNSVALKVTEALDNLH-FHRATREIHDFIVEDLSRWY IRLI
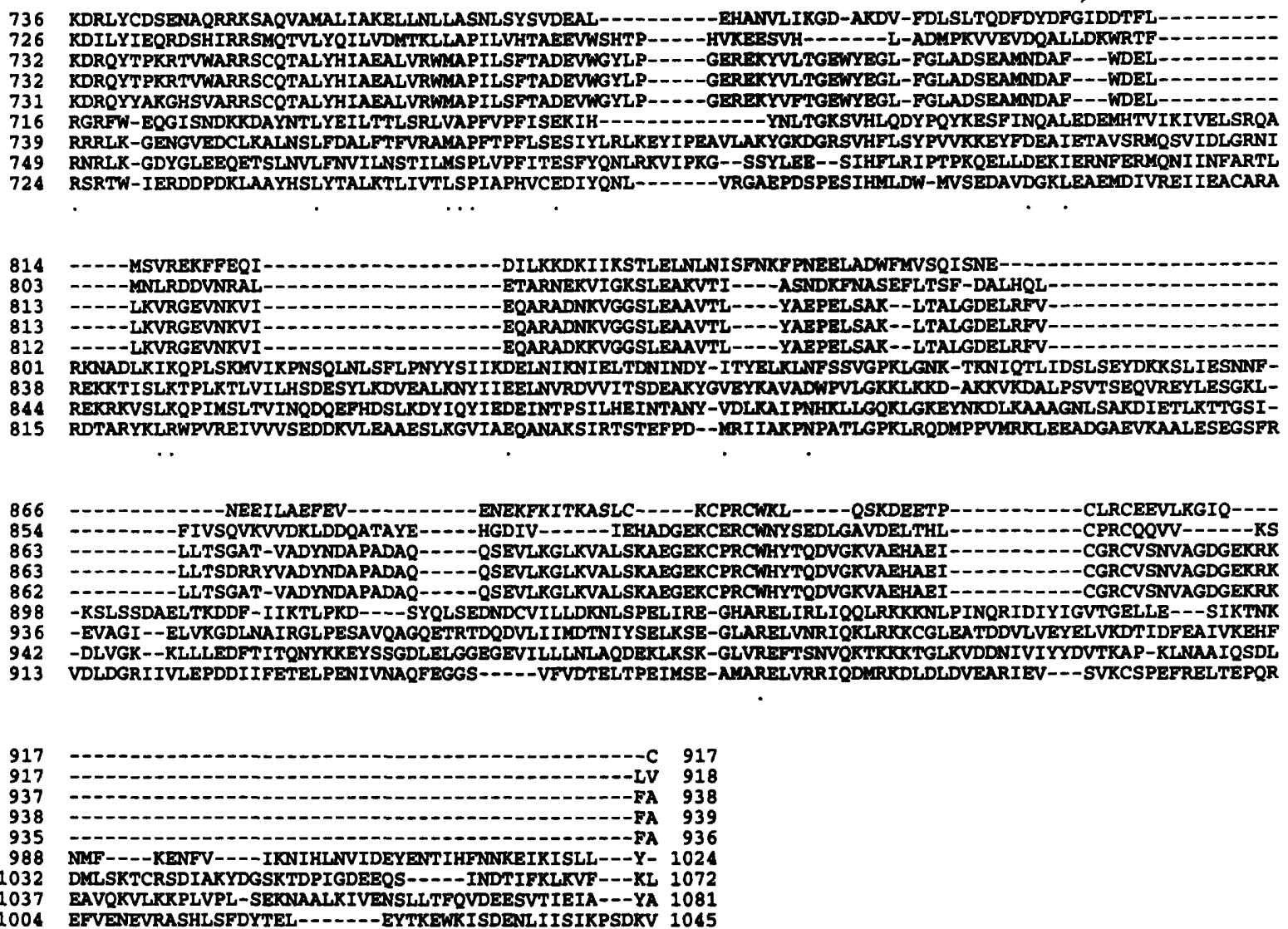

Fig. 3. Primary sequence homology alignment of IleRS from different organisms. Cj, $C$. jejuni; Sa1, Staph. aureus Oxford (Chalker et al., 1994); Sa2, Staph. aureus J2870, where the ileS gene conferred high-level resistance to mupirocin (Hodgson et al., 1994); Ec1, E. coli (Yu et al., 1984); Ec2, E. coli (Webster et al., 1984); Ec3, E. coli (GenBank accession no. S40549); SC, Sac. cerevisiae (Martindale et al., 1989); Tt, T. thermophila (Csank \& Martindale, 1992); and Mt, M. thermoautotrophicum Marburg (Jenal et al., 1991). Residues identical among all the organisms are indicated by asterisks under the sequence while residues with conserved changes are indicated by solid dots. The conserved sequences of motifs I-VII are overlined.

sequence extends to a 14 amino acid highly conserved motif, DGPPYANGHIHIGH (motif $I$ in Fig. 3). This motif is involved in the formation of the catalytic core of the enzyme activity (Shiba \& Schimmel, 1992). The KMSKS consensus motif serves as another signature sequence of class I aaRS, is perfectly conserved in all the listed IleRS sequences and is required for the binding of tRNA to the enzyme-bound isoleucyl adenylate during aminoacylation (Hountondji et al., 1990).

Approximately 25 amino acids downstream of the HIGH region is another strongly conserved region, motif II (Fig. 3 ). In this motif, a trimer peptide, GWD, is identical in all the sequences. This short, conserved peptide is believed to be involved in isoleucine binding to the IleRS (Clarke et al., 1988).

Fig. 3 demonstrates another four highly conserved motifs III, IV, V and VI. Motif III and motif VI are located at strong homology regions in the alignment of $E$. coli IleRS and other aaRSs such as ValRS, LeuRS and MetRS (Heck \& Hatfield, 1988). These regions are assumed to represent functionally related blocks although the specific function for these regions is not known. Motif IV is located in a region where sequences of different bacterial aaRSs show strong similarities (Shiba \& Schimmel, 1992; Martindale et al., 1989), while motif V was noted to be conserved in class I aaRSs, specifically in Met, Ile, Val and Leu tRNA 
synthetase (Ghosh et al., 1991; Borgford et al., 1987; Tzagoloff $e t$ al., 1988). Motif V contains an Arg at residue 470 of $C$. jejuni IleRS; the corresponding residue of MetRS in E. coli is believed to play a critical role in activation of methionine to bind to the enzyme (Ghosh et al., 1991).

Most of the conserved sequences are located close to the $\mathrm{N}$-terminus, as shown by others (Webster et al., 1984; Shiba \& Schimmel, 1992; Jenal et al., 1991; Martindale et al., 1989). However, some conserved sequences are located close to the $\mathrm{C}$-terminus. For instance, a zincfinger-like metal-binding site, $\mathrm{C}_{4}$ box in $C$. jejuni IleRS, composed of $\mathrm{Cys}^{890}-\mathrm{X}_{2}-\mathrm{Cys}-\mathrm{X}_{11}-\mathrm{Cys}-\mathrm{X}_{2}-\mathrm{Cys}^{905}$ is similar to that of E. coli $\mathrm{K} 12$ IleRS in Cys ${ }^{\mathbf{9 0 2}}-\mathrm{X}_{2}$-Cys-X-His- $\mathrm{X}_{14}$ Cys- $\mathrm{X}_{2}-\mathrm{Cys}^{925}$ and that of Staph. aureus Oxford IleRS in $\mathrm{Cys}^{887}-\mathrm{X}_{2}-\mathrm{Cys}-\mathrm{X}_{16}-\mathrm{Cys}-\mathrm{X}_{2}-\mathrm{Cys}^{910}$ where $\mathrm{X}$ represents various amino acids $\left(\mathrm{Cj}, \mathrm{Ec} 2\right.$ and $\mathrm{Sa} 1$ in Fig. 3). This $\mathrm{C}_{4}$ box is assumed to function in metal binding during tRNA aminoacylation (Miller \& Schimmel, 1992). Another putative consensus at the $\mathrm{C}$-terminus is a single amino acid $\mathrm{K}$ which is correspondingly located at amino acid 736 in C. jejuni IleRS, at amino acid 726 in Staph. aureus IleRS or at amino acid 732 in E. coli IleRS and is believed to interact with tRNA during aminoacylation (Shepard et al., 1992).

Maxicell analysis and the enzyme assay provided evidence of $C$. jejuni ileS gene expression in E. coli cells. The IleRS activity in E8-1-transformed E. coli $331 \mathrm{c}^{-}$was three times greater than in nontransformed $E$. coli $331 \mathrm{c}^{-}$.

The ile $S$ gene was mapped to the $1360-1812 \mathrm{~kb}$ region of the $C$. jejuni genome (Fig. 2). It is noteworthy that unlike E. coli, Enterobacter aerogenes and Pseudomonas fluorescens (Innis et al., 1984; Isaki et al., 1990a, b), C. jejuni does not harbour the $l s p$ gene (the gene encoding lipoprotein signal peptidase) immediately downstream of the ileS gene.

\section{ACKNOWLEDGEMENTS}

This work was supported by the Medical Research Council of Canada and University of Toronto, Faculty of Medicine Dean's Fund. Y. H. was supported by a Postdoctoral Fellowship Award from the Natural Sciences and Engineering Research Council of Canada. B. B. was supported by a Fellowship Award from the Medical Research Council of Canada.

\section{REFERENCES}

Aiba, H., Adhya, S. \& de Crombrugghe, B. (1981). Evidence for two functional gal promoters in intact Escherichia coli cells. $J$ Biol Chem 256, 11905-11910.

Altschul, S. F., Gish, W., Miller, W., Myers, E. W. \& Lipman, D. J. (1990). Basic local alignment search tool. $J$ Mol Biol 215, 403-410.

Borgford, T. J., Brand, N. J., Gray, T. E. \& Fersht, A. R. (1987). The valyl-tRNA synthetase from Bacillus stearothermophilus has considerable sequence homology with the isoleucyl-tRNA synthetase from Escherichia coli. Biochemistry 26, 2480-2486.

Burbaum, J. J. \& Schimmel, P. (1991a). Structural relationships and the classification of aminoacyl-tRNA synthetases. $J$ Biol Chem 266, 16965-16968.

Burbaum, J. J. \& Schimmel, P. (1991b). Assembly of a class I tRNA synthetase from products of an artificially split gene. Biochemistry 30 , $319-324$.
Chalker, A. F., Ward, J. M., Fosberry, A. P. \& Hodgson, J. E. (1994). Analysis and toxic overexpression in Escherichia coli of a staphylococcal gene encoding isoleucyl-tRNA synthetase. Gene 141, 103-108.

Chan, V. L. \& Bingham, H. L. (1991). Complete sequence of the Campylobacter jejuni gly $A$ gene encoding serine hydroxymethyltransferase. Gene 101, 51-58.

Chan, V. L. \& Bingham, H. L. (1992). Lysyl-tRNA synthetase gene of Campylobacter jejuni. J Bacteriol 174, 695-701.

Clarke, N. D., Lien, D. C. \& Schimmel, P. (1988). Evidence from cassette mutagenesis for a structure-function motif in a protein of unknown structure. Science 240, 521-523.

Csank, C. \& Martindale, D. W. (1992). Isoleucyl-tRNA synthetase from the ciliated protozoan Tetrabymena thermophila. $J$ Biol Chem 267, 4592-4599.

Cusack, S., Berthet-Colominas, C., Hărtlein, M., Nassar, N. \& Leberman, R. (1990). A second class of synthetase structure revealed by X-ray analysis of Escherichia coli seryl-tRNA synthetase at $2 \cdot 5 \AA$. Nature 347, 249-255.

Eriani, G., Delarue, M., Poch, O., Gangloff, J. \& Moras, D. (1990). Partition of $t R N A$ synthetases into two classes based on mutually exclusive sets of sequence motifs. Nature 347, 203-206.

Fisher, S. H. \& Nachamkin, I. (1991). Common and variable domains of the flagellin gene $f a A$, in Campylobacter jejuni. Mol Microbiol 5, 1151-1158.

Ghosh, G., Pelka, H., Schulman, L. H. \& Brunie, S. (1991). Activation of methionine by Escherichia coli methionyl-tRNA synthetase. Biochemistry 30, 9569-9575.

Hani, E. K. \& Chan, V. L. (1994). Cloning, characterization, and nucleotide sequence analysis of the argH gene from Campylobacter jejuni TGH9011 encoding argininosuccinate lyase. J Bacteriol 176, 1865-1871.

Heck, J. D. \& Hatfield, G. W. (1988). Valyl-tRNA synthetase gene of Escherichia coli K12. J Biol Chem 263, 868-877.

Henikoff, S. (1984). Unidirectional digestion with exonuclease III creates targeted breakpoints for DNA sequencing. Gene 28, 351-359.

Hodgson, J. E., Curnock, S. P., Dyke, K. G. H., Morris, R., Sylvester, D. R. \& Gross, M. S. (1994). Molecular characterization of the gene encoding high-level mupirocin resistance in Staphylococcus aureus J2870. Antimicrob Agents Chemother 38, 1205-1208.

Hountondji, C., Schmitter, J. M., Beauvallet, C. \& Blanquet, S. (1990). Mapping of the active site of Escherichia coli methionyltRNA synthetase: identification of amino acid residues labelled by periodate-oxidized $\mathrm{tRNA}{ }^{\mathrm{PMet}}$ molecules having modified lengths at the 3'-acceptor end. Biocbemistry 29, 8190-8198.

Innis, M. A., Tokunaga, M., Williams, M. E., Loranger, J. M., Chang, S., Chang, S. \& Wu, H. C. (1984). Nucleotide sequence of the Escherichia coli prolipoprotein signal peptidase $(l s p)$ gene. Proc Natl Acad Sci US A 81, 3708-3712.

Isaki, L., Beers, R. \& Wu, H. C. (1990a). Nucleotide sequence of the Pseudomonas fluorescens signal peptidase II gene $(l s p)$ and flanking genes. J Bacteriol 172, 6512-6517.

Isaki, L., Kawakami, M., Beers, R., Hom, R. \& Wu, H. C. (1990b). Cloning and nucleotide sequence of the Enterobacter aerogenes signal peptidase II (lsp) gene. J Bacteriol 172, 469-472.

Isaksson, L. A., Sköld, S.-K., Skjoldebrand, J. \& Takata, R. (1977). A protein for isolation of spontaneous mutants with temperature sensitive synthesis of RNA and/or protein. Mol \& Gen Genet 156, 233-237.

Jenal, U., Rechsteiner, T., Tan, P., Bùhlmann, E., Meile, L. \& 
Leisinger, T. (1991). Isoleucyl-tRNA synthetase of Methanobacterium thermoautotrophicum Marburg. J Biol Chem 266, 10570-10577.

Kim, N. W. \& Chan, V. L. (1989). Isolation and characterization of the ribosomal RNA genes of Campylobacter jejuni. Curr Microbiol 19, 247-252.

Kim, N. W., Bingham, H., Khawaja, R., Louie, H., Hani, E., Neote, K. \& Chan, V. L. (1992). Physical map of Campylobacter jejuni TGH9011 and localization of 10 genetic markers by use of pulsedfield gel electrophoresis. J Bacteriol 174, 3494-3498.

Kim, N. W., Lombardi, R., Bingham, H., Hani, E., Louie, H., Ng, D. \& Chan, V. L. (1993). Fine-mapping of the three ribosomal RNA operons on the updated genomic map of Campylobacter jejuni TGH9011 (ATCC 43431). J Bacteriol 175, 7468-7470.

Labigne, A., Courcoux, P. \& Tompkins, L. (1992). Cloning of Campylobacter jejuni genes required for leucine biosynthesis and construction of leu-negative mutant of $C$. jejuni by shuttle transposon mutagenesis. Res Microbiol 143, 15-26.

Laemmli, U. K. (1970). Cleavage of structural proteins during the assembly of the head of bacteriophage T4. Nature 227, 680-685.

Louie, H. \& Chan, V. L. (1993). Cloning and characterization of the gamma-glutamyl phosphate reductase gene of Campylobacter jejuni. Mol \& Gen Genet 240, 29-35.

Ludmerer, S. W. \& Schimmel, P. (1987). Gene for yeast glutamine tRNA synthetase encodes a large amino-terminal extension and provides a strong confirmation of the signature sequence for a group of the aminoacyl-tRNA synthetases. $J$ Biol Chem 262, 10801-10806.

Martindale, D. W., Gu, Z. M. \& Csank, C. (1989). Isolation and complete sequence of the yeast isoleucyl-tRNA synthetase gene (ILS1). Curr Genet 15, 99-106.

Miller, W. T. \& Schimmel, P. (1992). A metal-binding motif implicated in RNA recognition by an aminoacyl-tRNA synthetase and by a retroviral gene product. Mol Microbiol 6, 1259-1262.

Moras, D. (1992). Structural and functional relationships between aminoacyl-tRNA synthetases. Trends Biochem Sci 17, 159-164.

Nuijten, P. J. M., van Asten, F. J. A. M., Gaastra, W. \& van der Zeijst, B. A. M. (1990). Structural and functional analysis of two Campylobacter jejuni flagellin genes. J Biol Chem 265, 17798-17804.
Pei, Z. \& Blaser, M. J. (1993). PEBI, the major cell-binding factor of Campylobacter jejuni, is a homolog of the binding component in gram-negative nutrient transport systems. $J$ Biol Chem 268, 18717-18725.

Rould, M. A., Perona, J. J., Söll, D. \& Steitz, T. A. (1989). Structure of $E$. coli glutaminyl-tRNA synthetase complexed with tRNA ${ }^{\text {Gln }}$

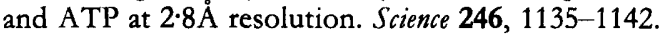

Sancar, A., Hack, A. M. \& Rupp, W. D. (1979). Simple method for identification of plasmid-coded proteins. J Bacteriol 137, 692-693.

Sanger, F., Nicklen, S. \& Coulson, A. (1977). DNA sequencing with chain-terminating inhibitors. Proc Natl Acad Sci USA 74, 5463-5467.

Schmidt, E. \& Schimmel, P. (1993). Dominant lethality by expression of a catalytically inactive class I tRNA synthetase. Proc Natl Acad Sci USA 90, 6919-6923.

Shiba, K. \& Schimmel, P. (1992). Tripartite functional assembly of a large class I aminoacyl tRNA synthetase. $J$ Biol Chem 267, 22703-22706.

Shepard, A., Shiba, K. \& Schimmel, P. (1992). RNA binding determinant in some class I tRNA synthetases identified by alignment-guided mutagenesis. Proc Natl Acad Sci USA 89, 9964-9968.

Smith, H. O. \& Birnstiel, M. L. (1976). A simple method for DNA restriction site mapping. Nucleic Acids Res 3, 2387-2399

Tzagoloff, A., Akai, A., Kurkulos, M. \& Repetto, B. (1988). Homology of yeast mitochondrial leucyl-tRNA synthetase and isoleucyl- and methionyl-tRNA synthetases of Escherichia coli. J Biol Chem 263, 850-856.

Webster, T., Tsai, H., Kula, M., Mackie, G. A. \& Schimmel, P、 (1984). Specific sequence homology and three-dimensional structure of an aminoacyl transfer RNA synthetase. Science 226, 1315-1317.

Yu, F., Yamada, H., Daishima, K. \& Mizushima, S. (1984). Nucleotide sequence of the isp $A$ gene, the structural gene for lipoprotein signal peptidase of Escherichia coli. FEBS Lett 173, 264-268.

Received 20 February 1995; revised 19 May 1995; accepted 14 June 1995. 